\title{
ASSESSING THE IMPACT OF TAX EVASION ON LONG-TERM FISCAL IMBALANCE: A SENSITIVITY ANALYSIS APPLICATION
}

\author{
Lucia Mihokova, Radovan Drab, Andrea Kralik*
}

\begin{abstract}
Tax evasion can have important consequences for the macroeconomic and social balance of a country, as well as for its monetary and fiscal development. A limited number of studies dealing with the consequences for fiscal imbalance are present, but their objectives vary a lot. This analysis has been conducted with the purpose to empirically assess the impact of the tax evasion changes on the public debt in the $28 \mathrm{EU}$ countries. The research considers the dynamics of public debt during the period of 21 years. The research is based on a probabilistic sensitivity analysis approach that was conducted individually for four clusters using @Risk of Palisade Decision Tools Package. The analysis showed a negative correlation between the tax evasion and the public debt, where the growth of the tax evasion is connected with the decrease of the public debt in a given country. The extent of the effect varies depending on the country, or more precisely on the groups of countries and is conditioned by other macroeconomic variables.
\end{abstract}

Keywords: public finance, long-term fiscal imbalance, tax evasion, probabilistic sensitivity analysis, simulation, EU countries

JEL Classification: $\mathrm{H} 26, \mathrm{H} 63$

\section{Introduction}

The empirical studies (such as Jílek, 2011; European Commission, 2014, 2000; etc.) confirmed that despite the growing revenues in recent years, also the government expenditures are showing an upward trend. The question of the persistent fiscal imbalance, in its short-term as well as in a long-term form, represents a crucial topic for governments of many world countries that are requesting an immediate, but durable solutions. One of the significant determinants of the fiscal development and one of the most discussed areas for an improvement in taxes collection, represents a higher control and better understanding of the tax evasion, and its impact on the government deficit and consequently on the public debt.

The theoretical work and empirical research of the national as well as the foreign authors (e.g. Novysedlak and Palkovičova, 2012; Cicek and Elgin, 2011; Slemrod and Yitzhaki, 2002) refer to important consequences of the tax evasion.

* Lucia Mihóková, Faculty of Economics, Technical university of Košice, Košice, Slovak Republic (lucia.mihokova@tuke.sk);

Radovan Dráb, Faculty of Economics, Technical university of Košice, Košice, Slovak Republic (radovan.drab@tuke.sk);

Andrea Kralik, Košice, Slovak Republic (andreakralik@yahoo.com).

This paper was supported by the Scientific Grant Agency of Ministry of Education, Science,

Research and Sport of the Slovak Republic and the Slovak Academy of Sciences under the grant VEGA No. 1/0967/15. 
Some authors (such as Sarac and Basar, 2014; Prinz and Beck, 2012; Bajada and Schneider, 2005, etc.) mainly point out the negative effects of the tax evasion (as part of the shadow economy) in the form of destabilization of economic and social balance and macroeconomic, monetary and fiscal development disturbance. On the other hand, authors such as (Orviska, 2013; Mara, 2012; Fassmann, 2007; Eilat and Zinnes, 2002; Uzunoglu, Yuruk and Atakisi, n.d.) describe a positive effects of the tax evasion on economic recovery, GDP growth and mitigation of risks in the economic activities. As authors state, the tax evasion as a part of shadow economy can support the competitiveness of the country, increase employment and provide resources to official economy.

In the context of the fiscal imbalance, various studies such as Cicek and Elgin (2011) or Aizenman, Kletzer and Pinto (2007) point out the tax evasion impact on the level of the public debt in a specific country. Authors (such as Sarac and Basar, 2014; Prinz and Beck, 2012) state that, in the context of public debt effects, a country with larger tax evasion should exhibit a larger debt-to-GDP ratio. In addition, countries with larger tax evasion should rely more on financing public expenditures by the inflation tax. Despite the adverse effects, the tax evasion has some positive side-effects, which is the ability to absorb potential economic and political shocks, as a reserve of flexibility that can support the fiscal development of the country. The positive effect of tax evasion is presented by authors such as Mara (2012); or Eilat and Zinnes (2002). Activities in the shadow economy, that include tax evasion, represent, especially in time of crisis, a "social safety valve", that can be an important source of national product's growth that contributes to debt-to-GDP ratio decrease.

Based on the example of presented research the tax evasion affects the public debt of a country through various channels and in many different ways, what can create a space for its empirical assessment.

\section{Objective, Methodology of the Research and Data}

The main objective of this research is to examine the impact of changes in the tax evasion on a long-term fiscal imbalance in the $28 \mathrm{EU}$ countries using a probabilistic sensitivity analysis. The sensitivity analysis has been conducted with the purpose to empirically assess the extent of the changes in the long-term fiscal imbalance (represented through the general government consolidated gross debt as an indicator) under the impact of changes in the tax evasion (represented through the estimations of shadow economy indicator) during the period 1995-2015 in 28 EU countries.

Tax evasion is often confused by the term tax avoidance. Despite the fact, that both tax evasion and tax avoidance represent two considerably significant determinants of tax collectiveness reduction and significant issues that are getting into the spotlight of economic leaders in relation to solving short-term and long-term fiscal imbalance, do these two parts of the shadow economy differ from a legal, intentional as well as a time point of view? This fact contributes to different approaches for measuring of their explanation, extent, consequences and resolution. Therefore, the authors usually treat them separately (e.g. Alm, 2012; Schneider, Raczkowski and Mroz, 2015; Raszkowski, 2013; Henry and Sansing, 2014; Guenther, 2014, Dyreng, Hanlon and Maydew, 2008, etc.). 
For the purpose of this article tax avoidance is defined as a legal tax reduction enabling national and international companies in the legal framework to optimise their tax liability. On the other side, the tax evasion is defined as an illegal tax reduction activity that represents a "bigger challenge" for governments in its identification and elimination of tax frauds.

Despite the importance of tax avoidance, this research is focussed only on the tax evasion measured by the size of the shadow economy. The extent of tax evasion is measured by different approach application, mostly including the evasion measurements via the shadow economy (Alm, 2012), and most often it is reported as a percentage of GDP. When examining the shadow economy, we must have in mind that there is a lack of reliable information on taxpayer compliance, and therefore, to some extent, the data can be misleading. To overcome these issues only available reliable shadow economy (and thus of the tax evasion) estimates for all 28 EU countries for the period 1995-2015 were taken from the empirical research carried out by Schneider (specifically Schneider and Enste, 2000; Schneider, Buehn and Montenegro 2010; Schneider, 2012 and Schneider, 2015). These data were used. Due to the incomplete data for the period 1995-1998 in case of some European countries, missing estimates were calculated as a moving average of three consecutive years.

The shadow economy estimates constructed by Schnieider and Enste (2000) are based on the Multiple Indicators Multiple Cause method (MIMIC) and are considered as a latent variable, which are related to causal variables - its key factors, and related to indicative variables derived from the latent variable. Despite these issues the method is considered to be the most commonly used and the most trusted one (Schneider and Williams, 2013; Schneider, Rackowski and Mroz, 2015).

The basic assumption of the analysis is that the long-term fiscal imbalance is negatively correlated with the extent of the tax evasion in the country. From the fiscal point of view, we suppose that the tax evasion growth is connected with a decrease of the public debt in a given country. This assumption about the inverse relationship (the higher tax evasion tends to lower public debt) between these two variables is based on the above mentioned theoretical and empirical research, as well as on the results of the previous analysis in the form of correlation analysis (Pavlikova and Kralik, 2014), which identified a negative relationship between the tax evasion and public debt in $75 \%$ of the $28 \mathrm{EU}$ countries. This assumption is based also on the results of the panel regression analysis, which pointed out a negative correlation with the short-term fiscal imbalance. To verify the stated assumption, the following Equation 1 of the public debt dynamics was set up:

$$
\Delta d_{t}=\left(i_{t}-g_{t}\right) d_{t-1}-p b_{t}
$$

where:

$\Delta d_{t}$ change in debt ratio at the time $t$,

$d_{t-1}$ value of the public debt at the time $t-1$ (i.e. the value of the inherited debt burden from the previous year),

$d \quad$ level of debt expressed as \% of GDP.

$p b_{t}$ primary balance at the time $t$, expressed as \% of GDP, which reflects the increase in debt due to the government's fiscal policy, 
$i_{t} \quad$ interest rate on the debt at the time $t$,

$g_{t}$ nominal GDP growth.

The secondary data on these indicators were obtained from the AMECO database, in line with the ESA 2010 methodology, for the 28 EU countries for the period 1995-2015 ${ }^{1}$.

Bispham (in Boskin, Flemming and Gorini, 1987) states that the share of the relative weight of the debt depends on the relationship between the interest rate $\left(i_{t}\right)$ and the economic growth $\left(g_{t}\right)$. For simulation purposes is the model structure represented by the condition (2). An increased sensitivity of the debt size on the changes of its main determinants (implicit interest rates, the nominal GDP growth and the debt value in the previous year) is expected.

$$
f\left(d_{t}\right)\left\{\begin{array}{l}
\text { if } \quad i_{t}<g_{t} \Rightarrow \Delta d_{t}=\frac{\left(1+g_{t}\right)}{\left(g_{t}-i_{t}\right)} d_{t-1}-p b_{t} \\
\text { if } \quad i_{t} \geq g_{t} \Rightarrow \Delta d_{t}=-p b_{t} \frac{\left(1+g_{t}\right)}{\left(i_{t}-g_{t}\right)} \frac{\left(1+i_{t}\right)^{t}}{\left(1+g_{t}\right)}+p b_{t} \frac{\left(1+g_{t}\right)}{\left(i_{t}-g_{t}\right)}+\frac{\left(1+i_{t}\right)^{t}}{\left(1+g_{t}\right)} d_{t-1}
\end{array} .\right.
$$

In the event that the interest rate is higher than the growth rate of product, the relative weight of the public debt significantly depends on the value of the primary balance $\left(p b_{t}\right)$ and on the debt level from the previous year $\left(d_{t-1}\right)$.

The probabilistic sensitivity analysis was carried out in individual countries' clusters that resulted from the conducted cluster analysis (as the first part of research). The purpose of this exploratory classification tool was to define an economically transparent and meaningful categorisation of the European Union member countries and to assess the similarities and differences of fiscal imbalances and the level of the tax evasion of countries. The motivation for this econometric techniques was the possibility to extract useful information, discover structures or certain patterns in a dataset and verify the assumption based on the countries' homogeneity in the primary balance and the level of tax evasion with a logical structure and ease of interpretation. The advantage of chosen clustering method was that it shows the high level of versatility and can produce multiple nested partitions organized as a tree (called a dendrogram), which allows user to choose different partitions based on the desired level of similarity (Suzuki \& Shimodaira, 2006).

Cluster analysis was based on five weighted and normalised segmentation criteria (GDP growth, deficit, debt, FRI and tax evasion) and conducted through hierarchical Ward's method with Euclidean distance (Kralik, Mihokova, Kovač, 2016). The segmentation criteria represent secondary data obtained from the AMECO database in line with the ESA 2010 methodology and from the empirical researches of Schneider, for the 28 EU countries for the period 1995-2015. Selected time period provided a sufficiently long period to avoid any short-term fluctuations in any of selected criteria, which ensures that the final clusters reflect realistic and not only random similarity of the countries within.

1 The characteristics of all used variables including units of measurement and in line with the used database are presented in Appendix. 
The sensitivity analysis also took into account the results of the panel regression analysis conducted for all identified clusters (as the second part of research). For the purpose of empirical assessment of the tax evasion impact on the development of the short-term fiscal imbalance a panel regression analysis was used. This motivation of the panel regression application was conditioned by the dataset involving two dimensions, which represent a cross-sectional time-series data and by the purpose itself to analyse changes over time, to estimate trends in social phenomena and to estimate a causal model. The econometric techniques used were conditioned by several advantages including ability to take into account individual heterogeneity of parameters and include variables at different levels, ability to more accurate inference of model parameters, uncover dynamic relationships as well as control or remove the impact and problem with the omitted variables (McManus, 2011; Torres-Reyna, 2007; Hsiao, 2007). Panel regression analysis allowed us also to generate more accurate predictions for individual outcomes, analysis of non-stationary time series and to capture the complexity of research problem.

Equation 1 expressing the public debt dynamics, which was the base for the sensitivity analysis, includes parameter primary balance $\left(p b_{t}\right)$. The value of the variable primary balance $\left(p b_{t}\right)$ was determined through the conducted model of the panel regression analysis. The econometric model (3) has been designed to consider the impact of tax evasion $\left(T E_{i}\right)$ and a wide range of control variables $\left(C O V A_{k_{i, t}}\right)$, economic and political factors $\left(E C O N_{l_{i, t}}\right)$, as well as fiscal determinants $\left(F I S C_{j_{i, t}}\right)$ in the pre-identified four clusters.

$$
F B_{i, t}=\beta_{0}+\beta_{1} T E_{i}+\Sigma_{k=2}^{m} \beta_{k} \operatorname{COVA}_{k_{i, t}}+\sum_{l=m+1}^{n} \beta_{l} \operatorname{ECON}_{l_{i, t}}+\sum_{j=n+1}^{r} \beta_{j} F I S C_{j_{i, t}}+\varepsilon_{i, t} .
$$

The variables were obtained in line with the ESA 2010 methodology from the AMECO database for the $28 \mathrm{EU}$ countries for the period 1995-2015.

The panel regression analysis was performed for three lagged periods (lag1-lag3) in order to assess the lagged effect of exogenous variables during the period 1995-2015 using fixed effect model and ordinary leased squared model. Values of the primary balance $\left(p b_{t}\right)$, applied in the equation of the public debt dynamics within the sensitivity analysis were calculated from the final equations of the models lag1 of the regression panel analysis and lag2 (only in Cluster 2). Equations 4-7 reflect the final effect of the tax evasion and the final effect of other statistically significant determinants of the primary balance for all considered clusters. The statistically insignificant control variables, economic and political factors, as well as fiscal determinants were not included into following equations.

$$
\begin{gathered}
p b_{t}=-0,87998 T E+6,33931 \text { GovEff }+3,86361 \text { PolStab }+0,23517 \text { MonFree }- \\
\text { 0,12482FinFree }+0,30289 H C P I-69,24211 \text { Cons }-47,97143 \text { Invest }+ \\
13,83976 \text { GrowthDebt }-0,27566 \text { LTIntererst }-6,97216 \text { Pop } 65-5,84175 \text { PopActive } \\
p b_{t}=-1,780451 \text { CofC }+0,053644 \text { InvestFree }+0,843933 \text { BurdenSSC }+ \\
\text { 0,443549BurdenTax }-0,17848 \text { GovSpend }-8,354601 \text { GrowthGDP }- \\
0,126966 \text { GapGDP }-26,713426 \text { Cons }-0,234324 \text { Umenpl }-0,913977 \text { Pop65 }
\end{gathered}
$$




$$
\begin{gathered}
p b_{t}=0,452484 T E+6,890251 \text { GovEff }-4,549947 \text { CofC }+2,183879 \text { Polstab } \\
+0,9159 \text { BusFree }-0,196934 \text { GAPGDP }-5,987780 \text { penes }-0,533214 \text { Unempl }- \\
9,86255 \text { GrowthDebt }+0,352331 \text { LTInteerst 01,151761PopActive } \\
p b_{t}=0,257181 \text { TE }-6,273935 \text { RofL }+3,261019 \text { GovEff }+0,472535 \text { BurdenSSC }- \\
0,144768 \text { GovSpend }-0,166617 \text { GapGDp }-44,696051 \text { Cons }-0,194517 \text { Unempl }+ \\
0,035947 \text { BusFree }-0,020298 \text { FinFree }
\end{gathered}
$$

Due to the uncertainty quantification addressing in the input parameters and due to the confidence intervals for point estimates capturing the model robustness was the probabilistic sensitivity analysis (PSA) selected for the research. As Baio and Dawid (2008) state, the PSA allows to consider input parameters as random quantities, where the uncertainty of the parameter's development is described by the defined probability distribution. The definition of probability distributions for model inputs in the probabilistic sensitivity analysis was carried out on the basis of input-related data and using the maximum likelihood estimator or Chi-Square test as the foundation for the distribution around the inputs. To perform the distribution selection, the fit distributions directly to the data approach, as described by Oakley and O'Hagan (2004), was applied. The purpose of performed sensitivity analysis was to empirically estimate the relation between selected input and output variables and to assess the extent of the changes in the long-term fiscal imbalance under the impact of changes in the tax evasion. PSA by controlling for the uncertainty in the inputs can provide unbiased results from the model also on latent variables. In this way, probabilistic models allow to control for the effects of joint uncertainty across all the parameters of the model to be considered. The sensitivity analysis, in the form of the probabilistic sensitivity analysis, has been conducted individually for each of the considered clusters in the program@Risk of Palisade Decision Tools Package.

The purpose of the PSA in the presented form was to investigate to what extent the tax evasion impacts the public debt and how much changes in tax evasion will change the public debt. The sensitivity analysis allowed to assess why the relative share of the public debt can decline despite the sustained primary budget deficits and, vice versa, why the public debt can increase, even when the economy reports surpluses. It also allowed us to assess "the sensibility" of the change in the volume of the public debt due to the changes in the tax evasion, in the control variables and other economic and fiscal determinants and to identify the most crucial factors, whose change impact the volume of the public debt to the greatest extent.

The sensitivity analysis was in the context of methodological approach carried out in three phases. The first phase of the sensitivity analysis included selection of the evaluation criterion, the method of calculation of the evaluation criterion and selection of the risk factors. As part of the selection of the evaluation criterion, we determined the variable, which would be simulated. In the case of the presented analysis, in line with the set objective, the simulated variable is represented by the general government gross debt $d_{t}$. The method of calculating the evaluation criterion is clear and based on the basic Equation 2 of the public debt dynamics. The selection of the risk factors (the exogenous variables) was conditioned by the basic objective of the analysis, i.e. to assess the extent of change in the long-term 
fiscal imbalance due to the changes in the tax evasion and the primary balance (taking into consideration also its statistically significant controls, economic and fiscal determinants from the panel regression analysis). In doing so, the presumption must be adhered that the considered factors of risk are those, whose changes are uncertain and to whose changes, the output of the simulation (the public debt) is sensitive.

In the second phase of the analysis we have estimated the probability distribution of the individual risk factors and determined the parameters of selected distributions. For each parameter (the considered exogenous factor) we estimated the probability distribution. The estimate was based on the objective determination of the probability distribution using the tool Palisade tools best Fit, which identified the most appropriate distribution of the probability for a given variable based on the entered existing values as stated by Oakley and O'Hagan (2004). Due to the absence of forecasted values of the individual variables (with the exception of some macroeconomic variables), we applied the best fit tool on the existing historical data used in the previous analysis. The selection of the appropriate probability distribution was made based on the Chi-Square test, which compares the individual expected frequencies (determined by the expected distribution), with the actual observed frequencies from the sample data. The objective determination was also supplemented with the subjective determination of the probability distribution, taking into consideration the extent of our personal beliefs in the incidence of a certain phenomenon.

The third phase represents the simulation itself. The process of random selection of specific values of risk factors from predefined distributions was performed through the Sampling function Latin Hypercube, with Mersenne Twister, the generator of the random variables, with the initial random seed. The Latin Hypercube was chosen instead of the Monte Carlo function due to a lower number of iterations (40.000). Also the Latin Hypercube (unlike the Monte Carlo) ensured the uniform and steady selection across the entire probability distribution of the risk factor. The programme generated the values of risk factors from their probability distributions (created a certain scenario) in each simulation step (40.000) and recalculated the model of the public debt change. Randomness and the objectivity of the entire simulation were ensured by the Mersenne Twister, which is already mentioned generator of the random variables. For presentation of the results Tornado diagram and spider diagrams were used.

\section{Results of Research}

\subsection{Results of cluster analysis}

The cluster analysis is an important exploratory data-mining tool, which is used in many research (e.g. Andrejovska, 2014; Vasiliauskaite and Stankevicius, 2009, etc.). In presented research the cluster analysis grouped $28 \mathrm{EU}$ countries into four clusters with an assigned level of homogeneity and with an emphasis on their fiscal situation and the level of tax evasion.

The final clusplot of clustering and final map of EU member countries into 4 clusters, based on five weighted and normalised segmentation criteria (GDP growth, deficit, debt, FRI 
and tax evasion) conducted through hierarchical Ward's method with Euclidean distance are shown in Figures 1 and 2.

Based on the cluster analysis results, the Cluster 1 consists of three countries (Belgium, Greece and Italy). These countries are characterized by the highest value of the public debt compared to the other clusters. The median public debt of this cluster is at the value of $111.781 \%$ of GDP, which is actually a three times higher debt than the level of the longterm fiscal imbalance in the Cluster 2. The group of these countries reported the highest tax evasion at $20.067 \%$ of GDP and the slowest economic growth at $2.913 \%$.

The countries in the Cluster 2 are Bulgaria, Estonia, Cyprus, Latvia, Lithuania, Hungary, Romania and Slovenia. The cluster of these countries is characterized by a median public debt of $30.092 \%$ of GDP, which compared to the other clusters represents the lowest level of debt, but also the highest value of tax evasion at $27.120 \%$ of GDP. The GDP growth is the highest among the clusters, with the value of $8.948 \%$ of GDP.

The Cluster 3 consists of nine countries (the Czech Republic, Ireland, France, Croatia, Malta, Poland, Portugal, Slovakia and the United Kingdom). The median value of the public debt of the countries in this cluster was at $55.616 \%$ of GDP, the level of the tax evasion was at the second highest value among the clusters at $22.020 \%$ of GDP and the economic growth at $6.463 \%$ of GDP.

The Cluster 4 is formed by the following eight countries: Denmark, Germany, Spain, Luxembourg, the Netherlands, Austria, Finland and Sweden. Countries are characterized by the median value of the public debt at $53.577 \%$ of GDP (which is the second highest level of debt compared to other clusters), the lowest estimated size of tax evasion among the clusters at $17.853 \%$ of GDP and with an economic growth at $4.017 \%$ of GDP.

Figure 1 | Ward's Clusplot of 28 EU Countries Organized in Four Clusters

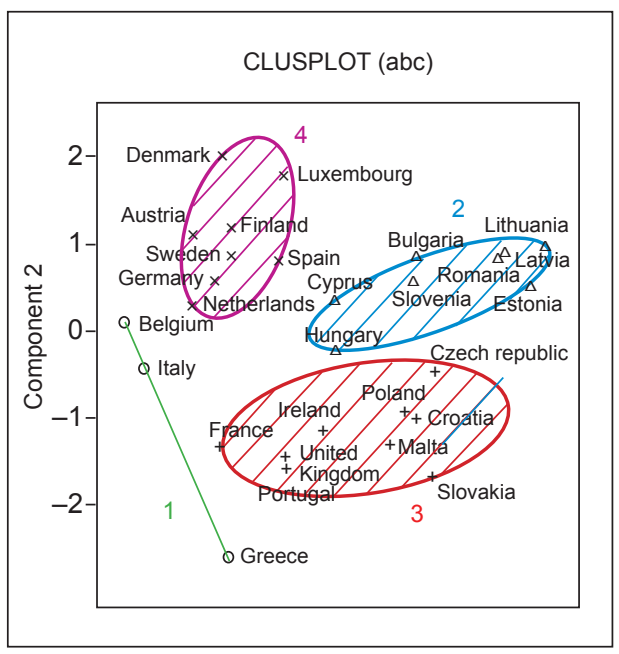

Source: Author's own elaboration
Figure 2 | Map Projection of the EU Countries Grouped in Four Clusters

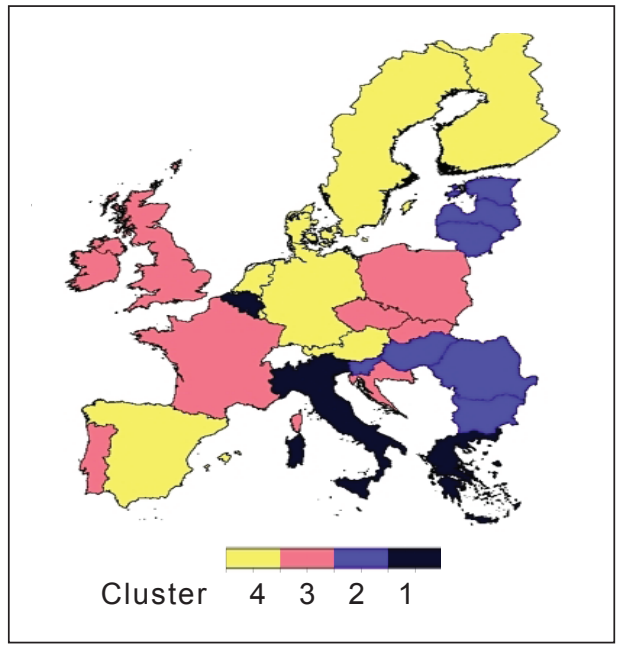

Source: Author's own elaboration 


\subsection{Results of sensitivity analysis: the effect of tax evasion}

The basic assumption of the simulation analysis is that the long-term fiscal imbalance, measured in the form of gross government debt is negatively affected by the tax evasion in a country. In the other words, we expect a negative correlation between variables, which means that between variables inverse relationship exist (the growth of tax evasion leads to the decrease of public debt). This assumption is conditioned by the reasons described in methodology of the research.

Values of the primary balance $\left(p b_{t}\right)$, applied in the Equation 1 of the public debt's dynamics within the probabilistic sensitivity analysis were calculated from the final equations of the models lag1 (as the methodology chapter states). Results of the concluded analysis based on the PSA results in the Cluster 1, Cluster 3 as well as in the Cluster 4 are in line with the formulated assumption.

As shown in the tornado diagram (Figure 3, 7 and 9), the public debt in Cluster 1, Cluster 3 and Cluster 4 is sensitive to the changes in the tax evasion. The growth of the tax evasion is associated with a decrease of the public debt in a country. This fact is proven by the final value of the regression coefficient tax evasion, from which it can be presumed that a change of tax evasion by one per cent causes a small decrease in the level of the public debt by 0.05 per cent (in Cluster 1 ) and by 0.03 per cent (both in Cluster 3 and 4 ). Despite the fact that the value of the regression coefficient is close to zero, based on the results can be stated, that the impact of tax evasion on the change of the public debt can be described as very weak, rather neutral, overall with a negative (inverse) relationship.

The effect of changes in the tax evasion on the public debt has also been confirmed from the dynamic point of view, which can be observed in the spider diagram (Figure 8). All scenarios of the tax evasion parameter increase have led to a decrease of the debt (a negative linear downward trend). This fact was confirmed for two other clusters: Cluster 3 and 4. Due to the limited versions of the software used and very small values of the regression coefficients, the scenarios of the development of changes in the tax evasion on the public debt could not be displayed in spider diagrams for all clusters. All results are consistent with the identified negative correlation in 100\% of the Cluster 1 cases, $75 \%$ of the Cluster 3 and 4.

The difference of the Cluster 2 in relation to the conducted sensitivity probabilistic analysis was that the risk factor primary balance $\left(p b_{t}\right)$, which entered the equation of the public debt dynamics (Equation 1), included the final impact of the determinants on the model lag2. The reason was that the determinant tax evasion was not selected as statistically significant in the model lag1, unlike in the other clusters. However, as the purpose of the analysis was to assess the effect of changes in the tax evasion on the public debt, we used the equation for $p b_{p}$ obtained from the model lag2.

The most important finding of the conducted simulation in Cluster 2 can be considered the fact that the assumption on the change of the public debt due to changes in the tax evasion was not confirmed. Based on the results, the effect of the tax evasion on the longterm fiscal imbalance is not present. This effect can be explained through activities impacting both, the government revenues, as well as the government expenditures (e.g. Toder, Nunns 
and Rosenberg, 2012; Schneider, 2004; Malička, Harčarikova, Gazda, 2012; Manolas, Rontos, Sfakianakis and Vavouras, 2013; Chianini, Marzano and Schneider, 2008). As Auerbach and Slemrod (1997) state the considerable fact should be that timing and other evasion behaviours are behaviours most responsive to tax changes, while changes in real productive activities are actually the least responsive.

\subsection{Results of sensitivity analysis: the effect of economic variables}

The results of the simulation show the significant effect of changes in three determinants of the debt, namely the nominal growth of GDP $\left(g_{t}\right)$, the implicit interest rate $\left(i_{t}\right)$ and the level of the previous debt $\left(d_{t-1}\right)$ in all four clusters. Coefficients of all stated factors are within all clusters in line with the empirical assumptions.

The results of the conducted simulations allowed to identify the most important factors, whose changes influence the volume of public debt in the countries to the greatest extent. The biggest change of the public debt occurs due to the influence of the GDP growth. According to the results of the regression coefficient, the increase of the nominal GDP by one per cent might lead to a decrease of the public debt by from $0.65-0.81$ per cent within all four clusters.

This significant negative correlation is visible also on the spider diagram (Figure 4, 6,8 and 10), where the scenarios of the GDP growth illustrate a decline in the public debt through the inversion function $\left(d_{t}\right)$ and $\left(g_{t}\right)$. This result is confirmed by many researchers (such as Mara, 2012; Mayes and Viren, 2000; Raisova, 2015; Jakubíkova, Tkačova and Banociova, 2014; Šoltes and Novakova, 2016; etc.) who state that overall economic situation of the country has a tendency to contribute to the reduction of the fiscal imbalance in the times of its boom and has a positive fiscal effects in the form of reduced debt volatility. In addition, the low economic growth is one of the major causes of the excessive fiscal imbalances within the EU.

The final regression coefficients, expressing the sensitivity of changes in the volume of public debt to changes in the considered risk factors, reflect that in all four clusters it is the debt from the previous season $\left(d_{t-1}\right)$ and the implicit interest rate on the debt $\left(i_{t}\right)$ that are increasing the public debt. The values of the regression coefficients in the tornado diagram (Figure 3, 5, 7 and 9) show that the sensitivity of the public debt on the changes of $\left(i_{t}\right)$ is at the value from $0.16-0.35$ within all clusters and on the changes of $\left(d_{t-1}\right)$ is at the value from $0.24-0.36$. The positive effect of these variables on the changes of the public debt is also confirmed from the dynamic point of view, which can be observed in the spider diagram within all four clusters (Figure 4, 6, 8 and 10). All growth scenarios of the above stated parameters lead to an increase in the level of public debt, which is confirmed by the linear upward trend. In Cluster 4 the relationship has in the case of the implicit interest rate value an exponential character. This effect is in line with the research of Tujula and Wolswijk (2004), who state that the interest rate signalizes the costs related to the debt financing in the country. High interest rates worsen the overall level of the fiscal balance through growing interest costs on newly issued debt and rolling debt. Also according to Bayar and 
Smeets (2009) the debt servicing costs from the previous year increase the real interest rate leads directly to worsening of long-term fiscal imbalance. The effect of previous debt ratio confirms research of Maltritz and Wüste (2015), who state that the dynamics of the debt ratio to GDP has a negative impact on the long-term fiscal imbalance as an increase in deficit leads to the growth of the debt interest payments and growth of current debt.

\subsection{Results of sensitivity analysis: the effect of primary balance}

Values of the primary balance $\left(p b_{t}\right)$, applied in the equation of the public debt dynamics were calculated from the final equations of the models lag1 of the regression panel analysis and lag2 (only in Cluster 2).

The overall effect of the primary balance $\left(p b_{t}\right)$ on the change of the public debt is negative in all four clusters in negative correlation meaning. Within the primary balance and within individual clusters, it is possible to identify the most significant determinants, on changes of which the public debt is the most sensitive.

Within Cluster 1 and Cluster 2 is among such factors the inflation (HCPI). The change of HCPI significantly impacts the changes of the public debt in the countries. The increase of HCPI by one per cent causes a decrease of the debt by 0.22 per cent (in the Cluster 1 ) and small decrease of the debt by 0.07 per cent (in the Cluster 2). The negative regression coefficient is in line with the assumption and research Tujula and Wolswijk (2004) that from the view of the state as a debtor, the growing inflation represents a positive determinant, as it undermines the real value of the nominal debt service of the state. This effect is confirmed also from the dynamic point of view observed in the spider diagram, where all scenarios of the growth in this parameter lead to a decrease of the debt (the slightly decreasing linear trend).

In the group of control variables (in the Cluster 1 and Cluster 4), several determinants were selected as significant. The index of the financial freedom (FinFree) as the fifth factor in terms of the size of the coefficient indicates the negative change in the public debt with the increase of the parameter financial freedom (the growth of FinFree by one per cent decreases the level of the public debt by 0.19 per cent (in the Cluster 1 ) and by 0.08 per cent (in the Cluster 4). The result of the simulation is consistent with the empirical assumption, where the increase of the financial freedom should cause a synergic effect in the interbank and business environment. As a consequence, the growth in the revenue side of budgets will allow the fiscal consolidation of the debt. The impact is also confirmed by the dynamic scenario of the changes in FinFree, where all scenarios of the parameter's growth lead to a decrease of the debt (the linear downward trend). The same effect on the debt's change was reported within the Cluster 1 in the case of the index of monetary freedom (MonFree), whose growth should decrease the level of debt in a country (the growth of the MonFree by one per cent causes a decrease of debt by 0.08 per cent). The significant factor of change in the public debt was the InvestFree index representing the freedom of the movement of investment capital (in the Cluster 2). As the results of the regression coefficients show in the tornado diagram (Figure 5), 
the increase of these index by one per cent decreases the level of the public debt by 0.04 per cent. Within the primary balance, the most significant identified determinant was the variable index BusFree (in the Cluster 3 and Cluster 4). The increase of the BusFree by one per cent leads to a low decrease in the public debt of the countries, which is confirmed by the value of the regression coefficient ( 0.05 and 0.07$)$. From a dynamic point of view, the individual decreases of this index have approximately the same linear impact on the changes of the debt, with a slightly decreasing trend. All stated above results are consistent with the expected effect, therefore can be stated that maintaining the sufficiently motivating and free business and financial environment, the support of the investment movements of the capital should contribute to the decrease of the debt ratio through the effects on the primary balance in the form of its improvement.

The sensitivity of the debt on the other factors: such as the share of population of the age over 65 years and over and the share of the active population (in the Cluster 1), political stability (in the Cluster 1), government effectiveness (in the Cluster 1 and 2), business freedom (Cluster 2), unemployment and control of corruption (in the Cluster 3), government spending and rule of law (in the Cluster 4) are negligible in terms of their final coefficients and it can be concluded that their effect on the debt change is rather neutral.

Figure 3 | Tornado Diagram for Cluster 1

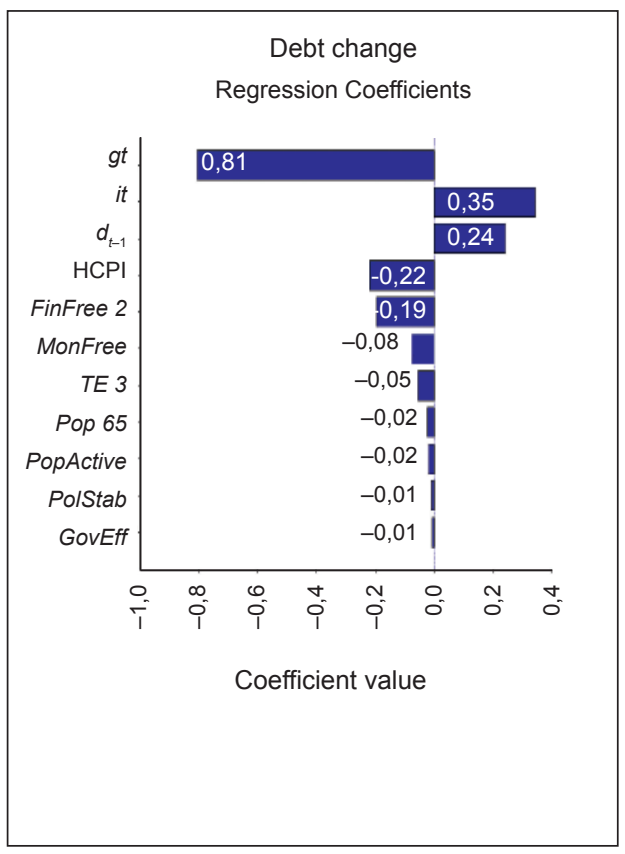

Figure 4 | Spider Diagram for Cluster 1

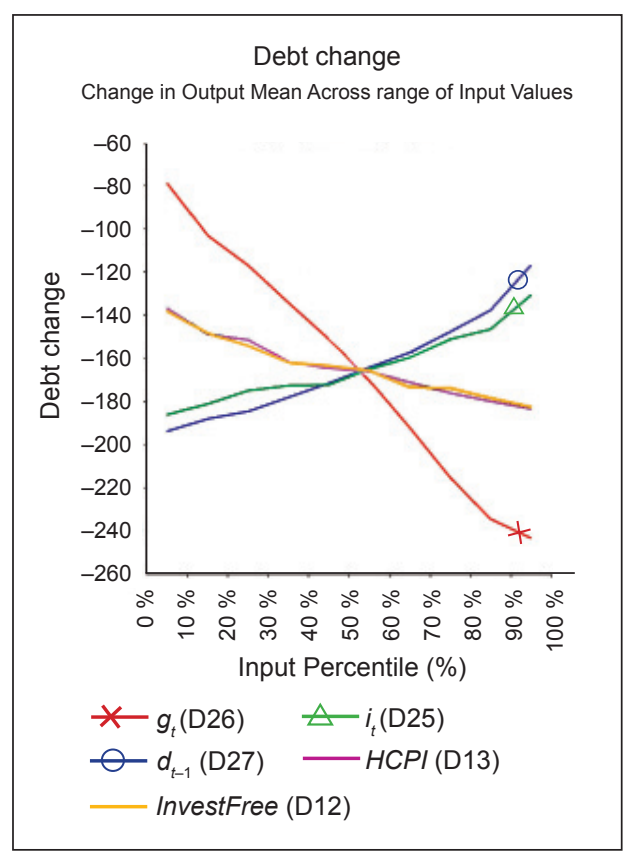

Source: Author's own elaboration based on testing results in @Risk 
Figure 5 | Tornado Diagram for Cluster 2

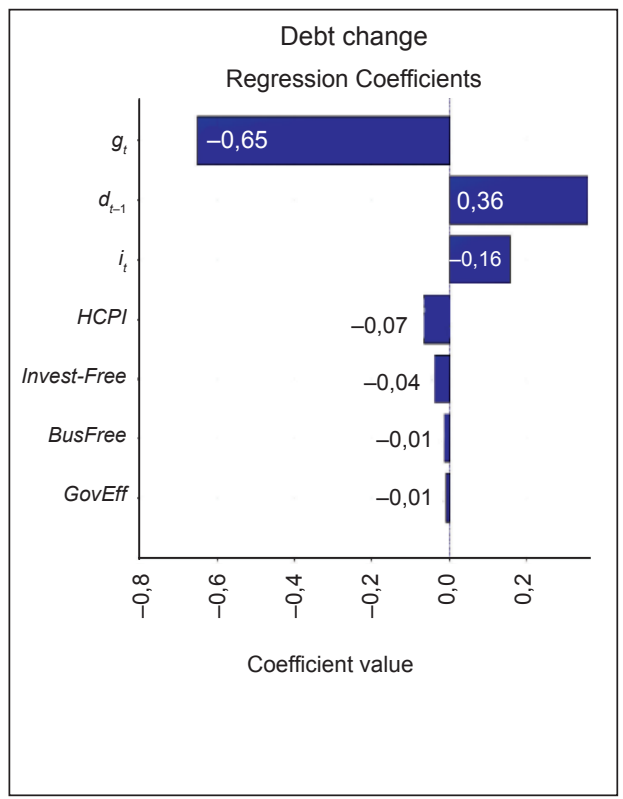

Figure 6 | Spider Diagram for Cluster 2

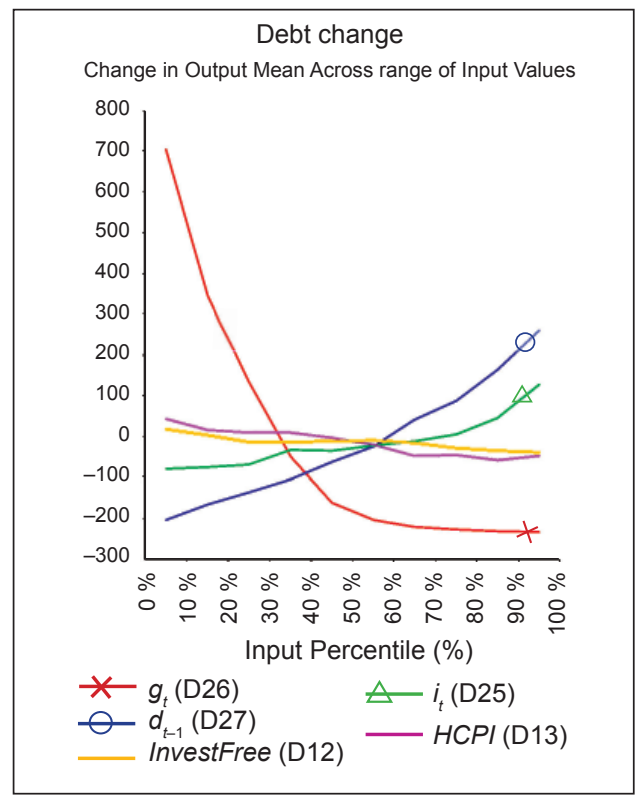

Source: Author's own elaboration based on testing results in @Risk

Figure 7 | Tornado Diagram for Cluster 3

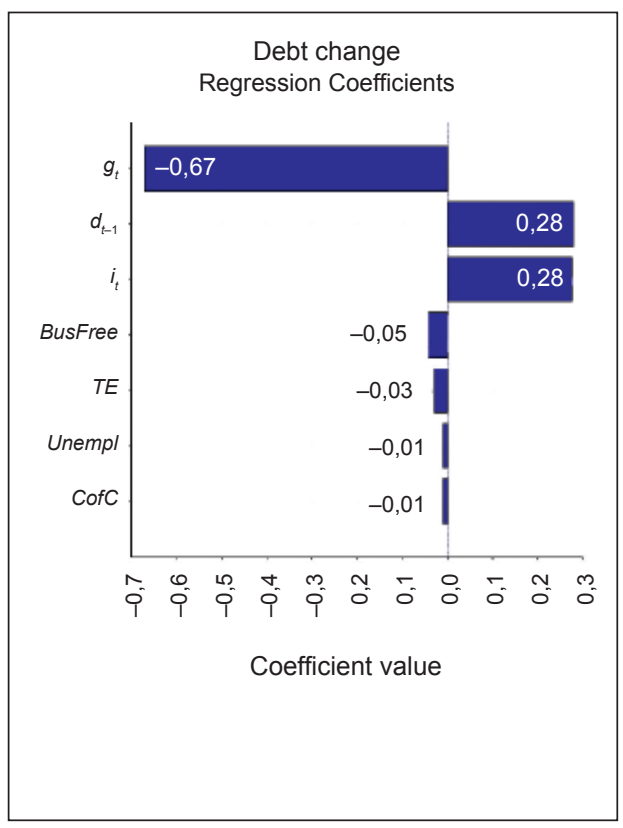

Figure 8 | Spider Diagram for Cluster 3

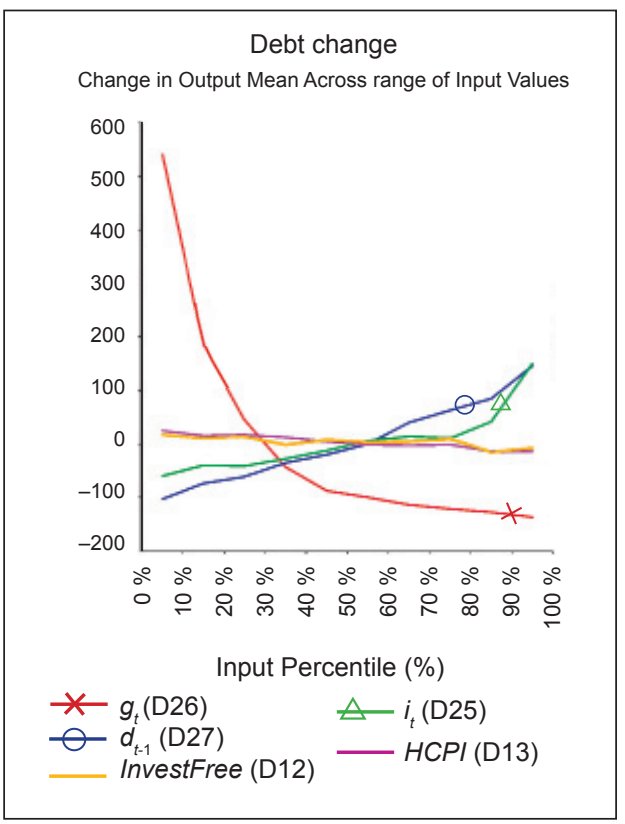

Source: Author's own elaboration based on testing results in @Risk 
Figure 9 | Tornado Diagram for Cluster 4

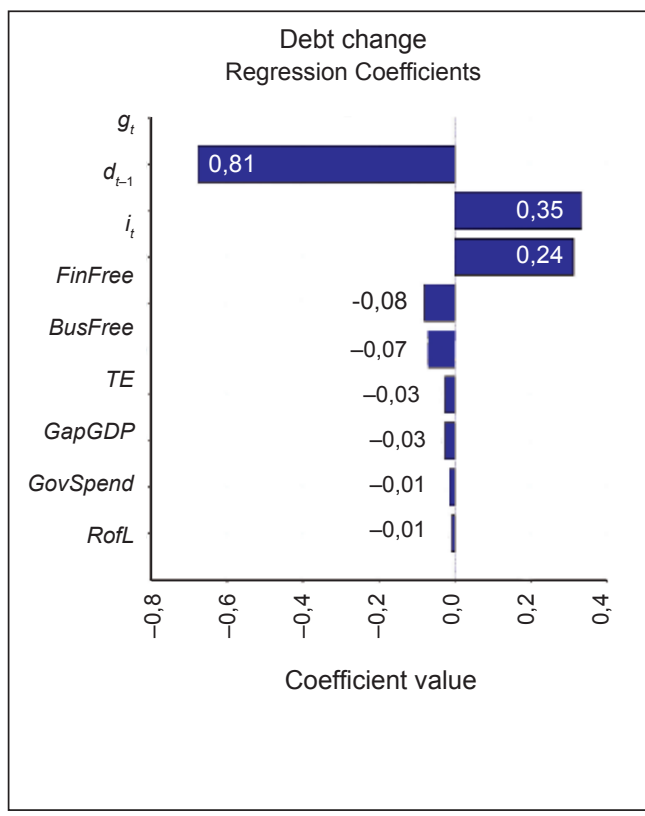

Figure 10 | Spider Diagram for Cluster 4

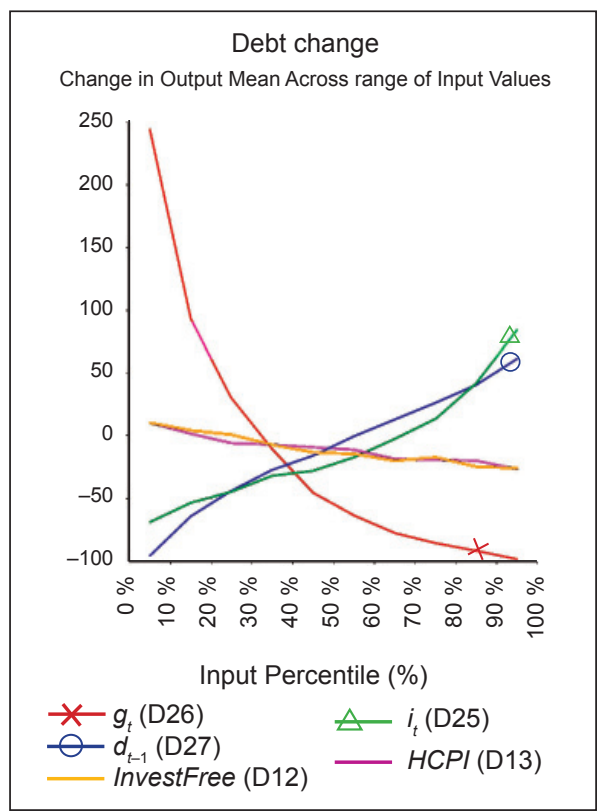

Note: Due to the limited versions of the software used, the scenarios of the development of changes in the tax evasion on the public debt could not be displayed in spider diagrams for all clusters.

Source: Author's own elaboration based on testing results in @Risk

\section{Discussion about the Effect of Tax Evasion's Results}

The sensitivity probabilistic analysis confirmed the main assumption about the negative correlation between the tax evasion and public debt. This inverse relation varies depending on the country, or more precisely on the groups of countries and is conditioned by other selected control variables, economic and political factors, as well as fiscal determinants. The verified assumption is in line with the theoretical and empirical research (such as Orviska, 2013; Mara, 2012; Fassmann, 2007; Eilat and Zinnes, 2002; Uzunoglu, Yuruk and Atakisi, n.d., etc.), who suppose that tax evasion should have a positive effects on economic recovery, GDP growth and mitigation of risks in the economic activities that contribute to the decrease of fiscal imbalance in the country.

As the tax evasion represents one of the main part of the shadow economy and is measured by the estimates of the shadow economy indicator, the positive effect of tax evasion on the public debt can be explained through the knowledge about the positive consequences of shadow economy.

The first positive effect of shadow economy on the public debt is connected from the economic perspective point of view with its functions as a kind of "social relief valve" where it during crises creates employment and income opportunities (Erdinc, 2016; Mara, 2012; Eilat and Zinnes, 2002; Gavurova and Šoltes, 2016). The shadow 
economy represents a shelter for many unemployed, particularly during the recession. As author state, companies that operate in a shadow economy have lower production costs, hence there is an increased labour demand when compared to the registered economy. Especially in time of crisis, when as it is assumed that part of the population is currently employed in the unofficial sector, because the official sector is not able to provide a labour supply. As the result of this increased employment, dependence on social welfare should decrease, so the expenditures of the government budget in the form of social contributions decreases. The second result of higher employment in shadow economy is that at income earned in the shadow economy is quickly spent in the official economy. The financial funds consumed in the formal economy lead to consumption expenditure growth and the revenues from indirect taxes growth. Many supporters therefore suppose that the shadow economy is an important source of the national product's growth and can possibly lower the public debt.

The positive effect of tax evasion as a part of shadow economy is connected also with another activities impacting the government revenues side. The big corporation and high-income taxpayers that tend to engage in the tax evasion activities more easily than other taxpayers. They can afford to hire lawyers and accountants to structure their income so that they owe as little tax as possible. As the high-income taxpayers are attempting to evade high amounts of taxes, the resources spent on implementing the activities related to the tax evasion are not negligible. The resources spent on evading taxes (e.g. in the form of legal fees to lawyers and accountants, etc.) are officially recorded and taxed and thus they increase the government revenues.

The decrease of public debt through the tax evasion can be explained also through the timing effect of tax evasion. As Auerbach and Slemrod (1997) state, the timing and other evasion behaviours are the behaviours most responsive to tax changes, while changes in real productive activities are actually the least responsive. Then, the size of the tax evasion in a given year does not necessarily reflect the shadow activities of that year and the impact on the budget might also be reflected with a longer time period delay.

Additionally, Orviska (2013) explains that the shadow economy may be perceived positively by some governments in such extent that the data, that are not recorded in official statistics. It leads to underestimation of the official estimates of living standards. The international assistance is often based on GDP per capita, either explicitly or informally. And a similar mechanism is used within the European Union. This means that the country whose calculated GDP is undervalued, will be in a better position in obtaining the transfers and aid from the international institutions and this will balance the losses caused by the existence of a shadow economy within a certain country.

\section{Conclusion}

The sensitivity analysis conducted individually in each of the four clusters (grouping $28 \mathrm{EU}$ countries based on the cluster analysis) allowed to identify factors with the impact on the public debt, with the emphasis on the tax evasion determinant. 
The used probabilistic sensitivity analysis verified assumption that the long-term fiscal imbalance in the form of general government public debt is negatively correlated with the tax evasion in the country in various extent. From the fiscal point of view, we have supposed that a growth of the tax evasion is connected with a decrease in the public debt in a given country. In terms of relation between the tax evasion and public debt can be concluded that tax evasion has a certain impact on the public debt of a country. This impact is in the form of negative correlation and varies depending on the country, or more precisely on the groups of countries and is conditioned by other macroeconomic variables. This main assumption has been confirmed in three clusters (Cluster 1: BE, EL and IT, Cluster 3: CZ, IE, FR, HR, MT, PL, PT, SK and UK and Cluster 4: DK, DE, ES, LU, NL, AT, FI and $\mathrm{SE}$ ), in which an increase of the tax evasion was accompanied by a decrease of public debt. Based on the resulting coefficients' values can be stated that in the case of Clusters 3 and 4 an identified final inverse relationship between the tax evasion and public debt was relatively weak, that supports a neutral relationship. The analysis showed no correlation of the tax evasion with the public debt in the countries grouped in the Cluster 2 (BG, EE, CY, LT, LV, HU, RO, SI). Among other identified significant factors were included: the nominal GDP growth (with the negative correlation effect in all four clusters), the implicit interest rate from the debt and the debt from the previous year (with a positive correlation effect) and some factors, which influence primary balance (the business freedom, unemployment rate and inflation) regardless of their inclusion in the group of control, economic or fiscal parameters (with a negative correlation effect).

Based on the conducted analysis it can be concluded that findings on the relationship between the tax evasion and long-term fiscal imbalance are relevant and are in in line with the theoretical and empirical research. It can be assumed that the resulting (unexplained) variability of the public debt can be explained by random failures and might be affected by several process-related factors, such as the use of estimated values (measuring the size of the tax evasion), the selection of segmentation criteria (used in the cluster analysis), the problems with the biased variables and lag time delays (in the panel regression analysis), or the use of the approximated equation of the public debt's dynamics (in the sensitivity analysis). These issues together with the economic fact that the issue of the tax evasion (including their estimated extent and their impact on the long-term fiscal imbalance represents) is a complex problem pointing to the necessity of its empirical assessment. Therefore, it is appropriate and desirable to extend the analysis of the tax evasion's impact on the fiscal imbalance in the future. 


\section{Appendix}

Characteristics of Main Variables Used in Sensitivity Analysis

\begin{tabular}{|c|c|c|c|c|}
\hline Variable & Label & Definition & UNIT & Source \\
\hline $\begin{array}{l}\text { General } \\
\text { government } \\
\text { consolidated } \\
\text { gross debt }\end{array}$ & $d_{t}$ & $\begin{array}{l}\text { total gross debt at nominal value } \\
\text { outstanding at the end of the year } \\
\text { of the sector of general government, } \\
\text { with the exception of those liabilities } \\
\text { the corresponding financial assets } \\
\text { of which are held by the sector of general } \\
\text { government. }\end{array}$ & $\%$ GDP & $\begin{array}{l}\text { AMECO } \\
\text { database }\end{array}$ \\
\hline Primary balance & $p b_{t}$ & $\begin{array}{l}\text { actual deficit (primary budget balance) } \\
\text { net of interest payments on consolidated } \\
\text { government liabilities and cyclical } \\
\text { component. }\end{array}$ & $\%$ GDP & $\begin{array}{l}\text { AMECO } \\
\text { database }\end{array}$ \\
\hline $\begin{array}{l}\text { Implicit interest } \\
\text { rate on debt }\end{array}$ & $i_{t}$ & $\begin{array}{l}\text { interest as percentage of gross public } \\
\text { debt of preceding year. Excessive deficit } \\
\text { procedure (based on ESA 2010). } \\
\text { Implicit interest rate is calculated due to } \\
\text { AMECO according equation: } \\
\text { (UYIGE t / UDGG t-1) × 100, where: } \\
\text { UYIGE = Interest including flows on swaps } \\
\text { and FRAs (Forward Rate Agreements); } \\
\text { general government; } \\
\text { UDGG = General government } \\
\text { consolidated gross debt. }\end{array}$ & $\%$ UDGG & $\begin{array}{l}\text { AMECO } \\
\text { database }\end{array}$ \\
\hline $\begin{array}{l}\text { Nominal GDP } \\
\text { growth }\end{array}$ & $g_{t}$ & $\begin{array}{l}\text { percentage growth of GDP in country. } \\
\text { The variable is calculated according } \\
\text { equation: ((UVGD t / UVGD t-1)*100) } \\
-100 \text {, where UVGD = Gross domestic } \\
\text { product at current prices in Mrd (milliard?) } \\
\text { ECU/EUR. }\end{array}$ & $\%$ & $\begin{array}{l}\text { AMECO } \\
\text { database }\end{array}$ \\
\hline
\end{tabular}

Source: Author's own elaboration according to AMECO

\section{References}

Aizenmann, J., Kletzer, K., Pinto, B. (2007). Economic Growth with Constraints on Tax Revenues and Public Debt: Implications for Fiscal Policy and Cross-Country Differences. National Bureau of Economic Research. Working Paper No. w12750, https://doi.org/10.3386/w12750

Alm, J. (2012). Measuring, Explaining, and Controlling Tax Evasion: Lessons from Theory, Experiments, and Field Studies. International Tax Public Finance, 19(1), 54-77, https://doi. org/10.1007/s10797-011-9171-2

Ameco. Annual Macroeconomic Database. [Online database]. Available online: http://ec.europa. eu/economy_finance/db_indicators/ameco/index_en.htm.

Andrejovska, A. (2014). Categorisation of the European Union Countries in Relation to Efficiency Adjustment of Value Added Tax Collection Using Cluster Analysis and Multidimensional Scalling. Journal of Applied Economic Sciences, 9(4), 580-590. 
Auerbach, A. J., Slemrod, J. (1997). The Economic Effects of the Tax Reform Act of 1986. Journal of Economic Literature, 35(2), 589-632.

Baio, G., Dawid, A. P. (2008). Probabilistic Sensitivity Analysis in Health Economics. Research Report 292/08, Department of Statistical Science, London: University College.

Bajada, C., Schneider, F. (2005). The Shadow Economies of the Asia-Pacific. Pacific Economic Review, 10(3), 379-401, https://doi.org/10.1111/j.1468-0106.2005.00280.x

Bayar, A., Smeets, B. (2009). Economic, Political and Institutional Determinants of Budget Deficits in the European Union. CESifo Group Munich. CESifo Working Paper No. 2611.

Bispham, J. A. (1987). Rising Public Sector Indebtedness: Some More Unpleasant Arithmetic, in Boskin, M. J., Flemming, J. S., Gorini, S., eds., Private Saving and Public Debt. Oxford: Blackwell, pp. 40-71.

Cicek, D., Elgin, C. (2011). Cyclicality of Fiscal Policy and the Shadow Economy. Empirical Economics, 41(3), 725-737, https://doi.org/10.1007/s00181-010-0409-0

Dyreng, S., Hanlon, M., Maydew, E. (2008). Long-Run Corporate Tax Avoidance. The Accounting Review, 83(1), 61-82, https://doi.org/10.2308/accr.2008.83.1.61

Eilat, Y., Zinnes, C. (2002). The Shadow Economy in Transition Countries: Friend or Foe? A Policy Perspective. World Development, 30(7), 1233-1254, https://doi.org/10.1016/s0305750x(02)00036-0

Erdinc, Z. (2016). The Reasons of Underground Economy, Its Results, Methods and the Turkish Case. Journal of Business \& Economic Policy, 3(1), 15-21.

European Commission (2014). Report on Public Finances in EMU 2014. European Economy Series. Belgium: European Commission, https://doi.org/10.2765/7626 (online)

European Commission (2000). Public Finances in EMU. European Economy Series. Belgium: European Commission.

Fassman, M. (2007). Stínova ekonomika a prace na černo. (The Underground Economy and Illegal Work). Prague: Sondy. ISBN 978- 80- 86846-21

Gavurova, B., Šoltes, M. (2016). Economic Aspects of Social Services Development in Slovakia in the Context of Demographic Changes. Scientific Papers of the University of Pardubice, Series D: Faculty of Economics and Administration, 37, 14-25.

Guenther, D. A. (2014). Measuring Corporate Tax Avoidance: Effective Tax Rates and Book-Tax Differences, (8 August 2014). Available online: https://ssrn.com/abstract=2478952

Hsiao, Ch. (2007). Panel Data Analysis - Advantages and Challenges. Test, 16(1), 1-22, https://doi. org/10.1007/s11749-007-0046-x

Henry, E., Sansing, R. (2014). Data Truncation Bias and the Mismeasurement of Corporate Tax Avoidance. Working Paper of University of Connecticut and Dartmouth College, https://doi. org/10.2139/ssrn.2329694

Chianini, B., Marzano, E., Schneider, F. (2008). Tax Rates and Tax Evasion: An Empirical Analysis of the Structural Aspects and Long-Term Characteristics in Italy. IZA. Institute for the Study of Labor. Discussion Paper No. 3447, https://doi.org/10.1007/s10657-011-9247-6

Jakubíkova, E., Tkačova, A., Banociova, A. (2014). Composite Leading Indicators of Economic Cycles of V4 Countries and their Comparison to the CLI of the Eurostat and the OECD. Politicka Ekonomie, 62(2), 194-215, https://doi.org/10.18267/j.polek.946

Jílek, M. (2011). Deficitní sklon veřejných financi a fiskalni pravidla. (Deficit Tendency of Public Finance and Fiscal Rules), in Kubatova, K., ed., Úloha veřejných financi v řešení problemu a dopadu současne krize. (The Role of Public Finance in Solving the Problem and the Impact of the Current Crisis). Prague: Wolters Kluwer ČR. 
Kralik, A., Mihokova, L., Kovač, V. (2016). Categorization of EU Member Countries: The Effect of Tax Evasion on Short-Term Fiscal Imbalance. Scientific Papers of the University of Pardubice, Series D: Faculty of Economic and Administration, 38(3), 56-67.

Malička, L., Harčarikova, M., Gazda, V. (2012). Determinants of Local Tax Revenues in EU Countries. European Journal of Economics, Finance and Administrative Sciences, 52, 120-126.

Maltritz, D., Wüste, S. (2015). Determinants of Budget Deficits in Europe: The Role and Relations of Fiscal Rules, Fiscal Councils, Creative Accounting and the Euro. Economic Modelling, 48, 222-236, http://doi.org/10.1016/j.econmod.2014.12.001

Manolas, G., Rontos, K., Sfakianakis, G., Vavouras, I. (2013). Tackling the Debt Crisis in Greece: The Role of the Underground Economy. Social Cohesion and Develoment, 8(1), 25-35, https://doi.org/10.12681/scad.9085

Mara, E. R. (2012). Determinants of Fiscal Budget Volatility in Old versus New EU Member States. School of Economics and Management, Technical University of Lisbon. Working Papers No. WP 31/2012/DE/UECE.

Mayes, D. G., Viren, M. (2000). The Exchange Rate Monetary Conditions in the Euro Area. Weltwirtschaftliches Archiv, 136(2), 199-231.

McManus, P. A. (2011). Introduction to Regression Models for Panel Data Analysis. Workshop in methods, Indiana University.

Novysedlak, V., Palkovičova, J. (2012). The Estimate of the Value Added Tax Revenue Loss. Institute for Financial Policy, Ministry of Finance of the Slovak Republic. Economic Analysis 25.

Oakley, J. E., O'Hagan A. (2004). Probabilistic Sensitivity Analysis of Complex Models: A Bayesian Approach. Journal of the Royal Statistical Society: Statistical Methodology, Series B, 66(3), 751-769, https://doi.org/10.1111/j.1467-9868.2004.05304.x

Orviska, M. (2013). Daňove úniky a tieňova ekonomika: Širšie implikacie v podnikaní a financiac. Inauguračna prednaška. (Tax Evasion and Shadow Economy: General Implications in Business and Finance). Košice: Technicka univerzita v Košiciach, Ekonomicka fakulta

Pavlikova, L., Kralik, A. (2014). The Impact of Tax Evasion on Public Deficit of Countries in V4 Region. Paper presented at the 5th Central European Conference in Regional Science (CERS). Košice.

Prinz, A., Beck, H. (2012). In the Shadow of Public Debt: Are There Relations between Public Debt and the Shadow Economy? Economic Analysis and Policy, 42(2), 221-236, https://doi. org/10.1016/S0313-5926(12)50022-6

Raczkowski, K. (2013), Gospodarka nieoficjalna w systemie zarza ‘dzania pa'nstwem. in Gołêbiowska, E., Raczkowski, K., ed., Zarza ، dzani-nowe perspektywy, (New managed persperctive), Przedsiêbiorczoœ'c i zarza ‘dzanie, Społeczna Akademia Nauk, Lodz, 353-354.

Raisova, M. (2015). Dual Approach to Growth Accounting. Application for Benelux and Baltic Countries. Journal of Applied Economic Sciences, 10(7), 1005-1013.

Sarac, M., Basar, R. (2014). The Effect of Informal Economy on the European Debt Crisis. Siyaset, Ekonomi ve Yönetim Arastirmalari Dergisi, (2), 25-37

Schneider, F. (2004). Shadow Economy, in Rowley, Ch., Schneider, F., eds., The Encyclopedia of Public Choices. Springer US, pp. 286-296.

Schneider, F. (2012). The Shadow Economy and Work in the Shadow: What Do We (Not) Know? The Institute for the Study of Labor (IZA). Discussion Paper Series. IZA DP No. 6423.

Schneider, F. (2015). Size and Development of the Shadow Economy of 31 European and 5 other OECD Countries from 2003 to 2015: Different Developments. [online]. Available online: http://www. econ.jku.at/members/Schneider/files/publications/2015/ShadEcEurope31.pdf 
Schneider, F., Enste, D. H. (2000). Shadow Economies: Size, Causes, and Consequences. Journal of Economic Literature, 38(1), 77-114, https://doi.org/10.1257/jel.38.1.77

Schneider, F., Williams, C. C. (2013). The Shadow Economy. The Institute of Economic Affairs, London: Hobbs the Printers, 27-28.

Schneider, F., Buehn, A., Montenegro, C. E. (2010). Shadow Economies All over the World - New Estimates for 162 Countries from 1999 to 2007. Revised version of WPS 5356. The World Bank, Policy Research Working Paper, https://doi.org/10.1596/1813-9450-5356

Schneider, F., Rackowski, K., Mroz, B. (2015). Shadow Economy and Tax Evasion in the EU. Journal of Money Laundering Control, 18(1), 34-51, https://doi.org/10.1108/JMLC-09-2014-0027

Slemrod, J., Yitzhaki, S. (2002). Tax Avoidance, Evasion and Administration, in Auerbach, A. J., Feldstein, M., eds., Handbook of Public Economics. 3, 1423-1470, https://doi.org/10.3386/ w7473

Suzuki, R., Shimodaira, H. (2006). Pvclust: An R Package for Assessing the Uncertainty in Hierarchical Clustering. Bioinformatics, 22(12), 1540-1542, https://doi.org/10.1093/ bioinformatics/btl117

Šoltes, V., Novakova, B. (2016). Assessment of Material Living Conditions by the Means of Integrated Indices in the Visegrad Group. Polish Journal of Management Studies, 13(1), 157-167, https://doi.org/10.17512/pjms.2016.13.1.15

Toder, E., Nunns, J., Rosenberg, J. (2012). Using a VAT to Reform the Income Tax. Tax Policy Center.

Torres-Reyna, O. (2007). Panel Data Analysis. Fixed and Random Efects Using Stata (v.4.2). Data and Statistical services. Princeton University.

Tujula, M., Wolswijk, G. (2004). What Determines the Fiscal Balances? An Empirical Investigation in Determinants of Changes in OECD Budget Balances. European Central Bank. Working Paper Series No. 422.

Uzunoglu, S., Yuruk, M. S., Atakisi, A. (n.d.). Underground Economy: It is an Economic Problem a Solution? [online]. Available at online: https://waleolusi.files.wordpress.com/2013/05/ underground-economy-is-it-an-economic-problem-or-a.pdf.

Vasiliauskaite, A., Stankevicius, E. (2009). Tax Burden Management and GDP Growth: Case of EU Countries. Economics \& Management, 14, 202-209. 